Jurnal DIALOGIKA Manajemen dan Administrasi

Homepage: https://ejournal.unma.ac.id/index.php/dialogika

Vol. 1 No.2 April 2020, halaman: $62 \sim 75$

E-ISSN: 2720-9865, P-ISSN: 2716-3563

DOI : https://doi.org/10.31949/dialogika.v1i2.2170

\title{
PENGARUH SUPERVISI KEPALA SEKOLAH DAN PENGAWAS TERHADAP KREATIVITAS GURU SERTA DAMPAKNYA TERHADAP PRESTASI SEKOLAH
}

\author{
Mohamad Ali \\ Mahasiswa Pascasarjana, Universitas Majalengka, Jawa Barat, Indonesia \\ e-mail korespondensi : mohamadali@gmail.com
}

Disubmit Februari 2020 , Diterima Maret 2020 , Diterbitkan April 2020

Submitted February 2020, Accepted March 2020 , Published April 2020

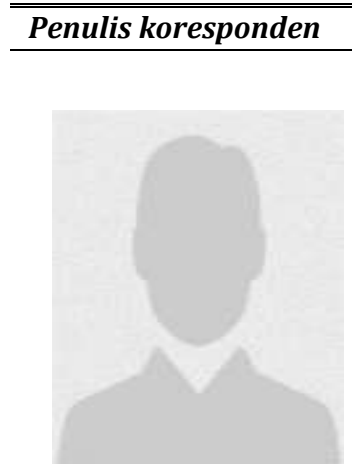

Jurnal DIALOGIKA

Manajemen dan

Administrasi

diterbitkan oleh

Program Studi

Administrasi Publik

Pascarjana Universitas

Majalengka \begin{abstract}
This study aims to determine: 1) Supervision of high school principals; 2) Supervision of high school supervisors; 3) The creativity of high school teachers; 4) Student achievement; 5) the effect of supervision by high school principals on teacher creativity; 6) the effect of supervision of high school supervisors on the creativity of teachers; 7) the influence of supervision of high school principals and high school supervisors on the creativity of teachers; 8) The effect of the creativity of high school teachers on school performance in Majalengka Regency. This research method is a quantitative research method with descriptive and verification analysis techniques. Descriptive method using the calculation of frequency distribution, scoring and average value, while the verification method using path analysis. The sampling technique was taken by cluster proportional random sampling. Descriptive research results indicate that supervision carried out by principals and school supervisors is in the quite good category, while creativity and student achievement are in the quite up to good category. The results of the study verify that the supervision conducted by the school principal and school supervisor has a positive and significant effect on the teacher's creativity either partially or simultaneously. Teacher creativity has a positive and significant effect on student achievement.
\end{abstract}

Keywords: Supervision of The Principal, Supervisor Supervision, Teacher Creativity, Student Learning Achievement

\begin{tabular}{l} 
Student Learning Achievement \\
\hline Abstrak \\
penelitian ini bertujuan untuk mengetahui : 1) Supervisi kepala sekolah; 2) Supervisi \\
sengawas sekolah; 3) Kreativitas guru; 4) Prestasi belajar siswa; 5) Pengaruh \\
sekolah terhadap kreativitas guru; 7) Pengaruh supervisi kepala sekolah dan \\
pengawas sekolah terhadap kreativitas guru; 8) Pengaruh kreativitas guru SMA \\
terhadap prestasi sekolah di Kabupaten Majalengka. Metode penelitian ini adalah \\
metode penelitian kuantitatif dengan teknik analisis secara deskriptif dan verifikatif. \\
Metode deskriptif dengan menggunakan perhitungan distribusi frekuensi, skoring \\
dan nilai rata-rata, sedangakn metode verifikatif dengan menggunakan analisis jalur. \\
Teknik sampling diambil secara cluster proporsional random sampling. Hasil \\
penelitian deskriptif menunjukkan bahwa supervisi yang dilaksanakan oleh kepala \\
sekolah dan pengawas sekolah berada pada kategori cukup baik, sementara \\
kreativitas dan prestasi belajar siswa berada pada kategori cukup sampai dengan \\
baik. Hasil penelitian secara verifikatif membuktikan bahwa supervisi yang dilakukan \\
oleh kepala sekolah dan pengawas sekolah berpengaruh positif dan signifikan \\
terhadap kreativitas guru baik secara parsial maupun simultan. Kreativitas guru \\
berpengaruh positif dan signifikan terhadap prestasi belajar siswa.
\end{tabular}

Kata Kunci : Supervisi Kepala Sekolah, Supervisi Pengawas, Kreativitas Guru, Prestasi Belajar Siswa 


\section{PENDAHULUAN}

Penyelenggaraan

pendidikan

berdasarkan Undang-undang Nomor 20 Tahun 2003 tentang Sistem Pendidikan Nasional bertujuan mewujudkan proses berkembangnya pribadi siswa sebagai generasi penerus bangsa yang menjadi faktor determinan bagi tumbuh berkembangnya bangsa dan negara Indonesia. Standar Proses Pendidikan Dasar dan Menengah yang tertuang dalam Permendikbud nomor 65 tahun 2013 menyatakan bahwa proses pembelajaran pada satuan pendidikan diselenggarakan secara interaktif, inspiratif, menyenangkan, manantang, memotivasi siswa untuk berpartisipasi aktif, serta memberikan ruang yang cukup bagi prakarsa, kreativitas, dan kemandirian sesuai dengan bakat, minat, dan perkembangan fisik serta psikologis siswa (Kemdikbud, 2013-b). UNESCO tentang peringkat Indeks Pengembangan Manusia (Human Development Index), yaitu komposisi dari peringkat pencapaian pendidikan, kesehatan, dan penghasilan per kepala yang menunjukkan, bahwa indeks pengembangan manusia Indonesia makin menurun. Saat ini Indonesia masih tertinggal dari Brunei Darussalam yang berada di peringkat ke-34. Brunai Darussalam masuk kelompok pencapaian tinggi bersama Jepang, yang mencapai posisi nomor satu Asia. Adapun Malaysia berada di peringkat ke-65 atau masih dalam kategori kelompok pencapaian medium seperti halnya Indonesia.Meskipun demikian posisi Indonesia saat ini masih jauh lebih baik dari Filipina (85), Kamboja (102), India (107), dan Laos (109).

Data Balitbang tahun 2003 bahwa dari 146.052 SD di Indonesia ternyata hanya delapan sekolah saja yang mendapat pengakuan dunia dalam kategori The Primary Years Program (PYP). Dari 20.918 SMP di Indonesia ternyata juga hanya delapan sekolah yang mendapat pengakuan dunia dalam kategori The Middle Years Program (MYP) dan dari 8.036 SMA ternyata hanya tujuh sekolah saja yang mendapat pengakuan dunia dalam kategori The Diploma Program (DP). Sementara dari hasil Uji Kompetensi Guru (UKG) tahun 2015, berdasarkan data dari Direktorat Jenderal
Guru dan Tenaga Kependidikan, jumlah peserta UKG adalah 2.699.516 dengan nilai rata-rata nasional 56,69. Adapun nilai ratarata UKG perjenjang sebagai berikut: SMA 61,74, SMK 58,30, SMP 58,25, SD 54,33, dan TK 59,65. Data nilai Ujian Nasional dua tahun terakhir, rata-rata nilai Ujian Nasional SMA Negeri se-kabupaten majalengka tahun 2016 adalah 61,46 sedangkan di tahun 2017 ini nilai rata-rata peserta Ujian Nasional adalah 48,32. Ini merupakan indikator hasil pembelajaran di kabupaten Majalengka yang belum memperlihatkan hasil memuaskan. Keberhasilan dalam pembelajaran dipengaruhi oleh faktorfaktor yang terlibat dalam semua kegiatan belajar mengajar, antara lain siswa, guru, kebiajakan pemerintah dalam membuat kurikulum, serta dalam proses belajar seperti metoda, sarana dan prasarana dan pendekatan belajar yang digunakan. Kondisi riil dalam pelaksanaannya latihan yang diberikan tidak sepenuhnya dapat meningkatkan kemampuan siswa dalam menerapkan konsep. Rendahnya mutu pembelajaran dapat diartikan kurang efektifnya proses pembelajaran. Penyebabnya dapat berasal dari siswa, guru maupun sarana dan prasarana yang ada, minat dan motivasi siswa yang rendah, kinerja guru yang rendah, serta sarana dan prasarana yang kurang memadai akan menyebabkan pembelajaran menjadi kurang efektif.

Mengacu kepada Peraturan Pemerintah No 19 Tahun 2005 tentang Standar Nasional Pendidikan ditandaskan pada Pasal 55 ayat 1, bahwa tugas seorang pengawas sekolah berat dan penuh tantangan. Konsekuensinya, pengawas harus memahami tugas dan tanggung jawabnya, sehingga hal ini erat kaitannya dengan proses rekrutmet yang dilakukan Dinas Pendidikan.

Guru sebagai salah satu komponen proses pembelajaran merupakan pemegang peran penting, bukan hanya sekedar penyampai materi melainkan sebagai sentral pembelajaran. Proses pembelajaran adalah suatu proses interaksi atau hubungan timbal balik antara guru dan anak didik dalam satuan pembelajaran. Sebagai pengatur sekaligus pelaku dalam proses 
pembelajaran, gurulah yang mengarahkan bagaimana proses pembelajaran itu dilaksanakan. Karena itu guru harus dapat membuat suatu pembelajaran lebih efektif juga menarik sehingga bahan pelajaran yang disampaikan akan membuat anak didik merasa senang dan merasa perlu untuk mempelajari bahan pelajaran tersebut. Pencapaian tujuan pembelajaran, tidak hanya tergantung pada guru, tetapi ditentukan oleh banyak faktor, diantaranya adalah faktor perangkat pembelajaran yang tersedia. Perangkat pembelajaran akan sangat membantu guru dan anak didik dalam upaya memahami konsep-konsep materi yang akan mereka pelajari. Melalui pengawasan ini tampilan guru dipantau sedemikian rupa oleh pengawas atau penilik yang melibatkan kerjasama secara harmonis antara guru. Artinya guru diibaratkan sebagai bawahan yang harus tunduk pada apa dan bagaimana yang diperintahkan oleh pengawas. Sedangkan dalam pandangan modern pengawasan ditujukan untuk memperbaiki situasi belajar mengajar, yaitu pengawasan dilakukan sebagai bantuan bagi guru dalam meningkatkan kualitas mengajar untuk membantu siswa agar lebih baik lagi dalam belajar. Walaupun demikian, dalam kenyataan yang ada, masih banyak guru beranggapan bahwa pengawasan indentik dengan inspeksi, akibatnya muncul ketakutan dan tidak berani berinisatif apalagi berinnovasi.

Dalam proses belajar mengajar sering dijumpai sebagian siswa belum mengerti dan memahami materi yang disampaikan oleh guru. Idealnya, seorang guru harus memiliki dan menerapkan strategi tertentu supaya siswa dapat belajar secara efektif. Hal ini bisa saja dilakukan dalam berbagai bentuk, misalnya dengan menata pengelolaan pengajaran yang paling cocok dengan karakter peserta didik dan materi ajar serta lebih memperhatikan keadaan siswa baik fisik maupun psikis. Selain itu, guru pun sebaiknya mampu menciptakan pembelajaran yang kreatif dan menyenangkan.

Guru diberi kemampuan untuk menyesuaikan diri dengan berbagai situasi dan tantangan perkembangan pendidikan. Perubahan dan perkembangan dalam dunia pendidikan berimplikasi kepada guru untuk dapat beradaptasi dengan cepat dan tepat. Seringkali tingkat keragaman dan kedalaman permasalahan dalam pendidikan dan pembelajaran sangat kompleks. Hal itu dikarenakan tantangan dan permasalahan pembelajaran dapat berasal dari faktor ekstern guru seperti siswa yang tidak semangat belajar, media pembelajaran yang kurang memadai, dsb. maupun intern guru seperti kurang menguasai teknologi informasi, dsb. Guru seyogianya dapat memikirkan dan bertindak dengan cara yang tepat untuk dapat menguraikan kompleksitas tantangan dan memikirkan berbagai alternatif tindakan yang dapat dilakukan untuk menjawab berbagai masalah tersebut. Di sekolah seorang guru dapat menerapkan pola pembelajaran yang memiliki semangat untuk meningkatkan kreativitas. Dalam konteks pembelajaran siswa, guru dapat tetap tegas bertindak atas dasar aturan-aturan baku namun tetap memberikan kesempatan dan memfasilitasi peningkatan kreativitas positif siswa. Berbagai alasan dari mulai tabu, pamali, kata orang tua, tidak menjadikan seorang guru membatasi kreativitas siswa, tetapi menjadikan kreativitas guru dan siswa selaras sesuai norma dan nilai yang baik.

Bersikap kreatif membawa dampak positif pada diri guru dan siswa. Pada diri guru mendorong aktulisasi potensi yang dimiliki. Bagi siswa memberikan kepuasaan karena tindakan yang dilakukan dalam waktu yang lebih cepat, memberi hasil yang lebih tepat, hasil yang lebih banyak, dan merupakan hasil karya yang orisinal dan unik. Bagi seorang siswa belajar merupakan suatu kewajiban. Berhasil atau tidaknya seorang siswa dalam pendidikan tergantung pada proses belajar yang dialami oleh siswa tersebut. Prestasi belajar tidak dapat dipisahkan dari perbuatan belajar, karena belajar merupakan suatu proses, sedangkan prestasi belajar adalah hasil dari proses belajar tersebut. Prestasi belajar adalah produk akhir dari sebuah proses belajar berupa kemampuan menggunakan pengetahuan dan konsep belajar yang merupakan dasar peningkatan prestasi belajar siswa. Effendi (2007:29) menyatakan bahwa ketidaktenangan dan 
kerisauan atas hal-hal kecil seringkali mengganggu pelajar yang membuat meraka sulit untuk berkonsentrasi dengan baik, sehingga mempengaruhi prestasi belajarnya. Dengan berpedoman pada pernyataan tersebut dapat dijelaskan bahwa kondisi lingkungan berdampak langsung terhadap kejiwaan dan mental siswa yang pada akhirnya akan berpengaruh pula pada prestasi belajar. Hal-hal kecil seringmenjadi batu sandungan terhadap kegiatan belajar. Dengan demikian dibutuhkan dukungan dan bantuan guru maupun orang tua agar siswa dapat terlepas dari kondisi yang mampu mengganggu konsentrasi belajar mereka. Hardwinoto dan Setiabudhi (2006:36) menjelaskan bahwa agar anak dapat belajar dengan baik, mereka memerlukan lingkungan yang menyenangkan agar mereka dapat mengingat dengan baik informasiinformasi yang diterima dan perlu adanya pengulangan agar tercipta ingatan jangka panjang. Lebih jelasnya dapat dinyatakan bahwa untuk melatih siswa agar dapat memahami dan menguasai materi pelajaran dengan baik, maka perlu adanya lingkungan belajar yang kondusif. Selanjutnya informasi dan pengetahuan yang telah disampaikan sebaiknya sering diulang sedemikian rupa sampai siswa mampu menguasai secara baik.

Hakim (2007:25) menyatakan
bahwa bagi seseorang yang ingin
meningkatkan prestasi belajarnya ia
harus mampu menemukan faktor
penghambat belajar dan mengatasi
hambatan belajar secara bijak. Langkah
awal untuk meningkatkan prestasi
belajar harus berlangsung dari dalam diri
peserta didik. Jika kondisi yang ada
dalam diri siswa mampu mendorong
untuk memperbaiki prestasi yang telah
dicapai maka akan terbentuk sebuah
motivasi memenuhi keinginan tersebut.
Adapun faktor lingkungan berperan
sebagai faktor pemicu lahirnya kesadaran
untuk mencapai prestasi belajar optimal.
Siswa yang mengalami kesulitan belajar,
lama kelamaan akan mengalami frustasi
dan kehilangan rasa percaya diri.
Selanjutnya ia akan berusaha mencari

pelarian lain yang dapat memuaskan rasa ketidakmampuan tersebut. Menjaga agar kondisi tersebut tidak berkepanjangan dibutuhkan langkah konkrit dari siswa dan pembimbing untuk membantu siswa agar dapat melepaskan diri dari kesulitan belajar yang dialaminya. Di dalam belajar, terjadi proses berfikir, seseorang dikatakan berfikir jika mampu melakukan kegiatan mental, kegiatan fisik atau kegiatan fisik dan mental secara bersamaan. Dalam kehidupannya manusia tidak terlepas dari perbuatan fisik dan mental sehingga jelas bahwa proses belajar sangat dibutuhkan dalam kehidupan manusia. Selanjutnya prestasi belajar merupakan hasil akhir yang ditimbulkan dari kegiatan mental, kegiatan fisik atau kegiatan secara bersama-sama antara fisik dan mental. Dengan demikian, dapat dinyatakan beberapa rumusan dari pengertian prestasi belajar, diantaranya bahwa "prestasi belajar adalah penguasaan pengetahuan atau materi yang dikembangkan oleh mata pelajaran". Hasil belajar menurut Nana Sudjana adalah "kemampuan yang dimiliki siswa, setelah ia menerima pengalaman belajarnya". Dalam dunia pendidikan, bentuk penilaian dari suatu prestasi biasanya dapat dilihat atau dinyatakan dalam bentuk simbol huruf atau angka-angka. Jadi, prestasi belajar adalah hasil yang diraih oleh siswa dari aktivitas belajarnya yang ditempuh untuk memperoleh pengetahuan dan keterampilan yang dapat diwujudkan dengan adanya perubahan sikap dan tingkah laku dan pada umumnya dinyatakan dalam bentuk simbol huruf atau angka-angka.

Prestasi belajar yang didapatkan oleh seorang siswa bersifat sementara kadang kala dalam suatu tahapan belajar, siswa yang berhasil secara gemilang dalam belajar, sering pula dijumpai adanya siswa yang gagal. Seperti angka raport rendah, tidak naik kelas, tidak lulus ujian akhir dan sebagainya. Dalam dunia pendidikan, bentuk penilaian dari suatu prestasi biasanya dapat dilihat atau dinyatakan dalam bentuk simbol huruf atau angka-angka. Jadi, prestasi belajar adalah hasil yang diraih oleh siswa dari aktivitas belajarnya yang ditempuh 
untuk memperoleh pengetahuan dan keterampilan yang dapat diwujudkan dengan adanya perubahan sikap dan tingkah laku dan pada umumnya dinyatakan dalam bentuk simbol huruf atau angka-angka. Bertitik tolak dari permasalahan dan harapan mengenai usaha yang telah dilakukan dengan hasil yang telah dicapai, seperti yang telah dikemukakan diatas, maka penulis terdorong untuk melakukan penelitian dengan judul "Pengaruh Supervisi Kepala Sekolah dan Pengawas Sekolah Terhadap Kreativitas Guru serta Dampaknya Terhadap Prestasi Belajar Siswa SMA Kabupaten Majalengka". Untuk melakukan kajian tersebut, ditetapkanlah semua SMA se-Kabupaten Majalengka sebagai lokasi penelitian dengan sampel secara proporsional menggunakan rumus SLOVIN

\section{TINJAUAN PUSTAKA}

Kegiatan utama pendidikan di sekolah dalam rangka mewujudkan tujuannya adalah kegiatan pembelajaran, sehingga seluruh aktivitas organisasi sekolah bermuara pada pencapaian efesiensi dan efektivitas pembelajaran. Oleh karena itu, salah satu tugas kepala sekolah adalah sebagai supervisor, yaitu mensupervisi pekerjaan yang dilakukan oleh tenaga kependidikan. Sergiovani dan Starrat (1993), Mulayasa (2009 : 111) menyatakan bahwa "Supervision is a process designed to help teacher and supervisor leam more abaut their practice; to better able to use their knowledge ang skills to better serve parents and schools; and to make the school a more effective learning community". Kutipan tersebut menunjukan bahwa supervisi merupakan suatu proses yang dirancang secara khusus untuk membantu para guru dan supervisor dalam mempelajari tugas sehari-hari di sekolah agar dapat menggunakan pengetahuan dan kemampuan untuk memberikan layanan yang baik pada orang tua siswa dan sekolah, serta berupaya menjadikan sekolah sebagai masyarakat belajar yang lebih efektif. Menurut Arikunto (2004:33) sasaran supervisi ada tiga macam, yaitu pembelajaran, pendukung kelancaran pembelajaran atau administrasi dan kelembagaan.

Tugas dan kewajiban kepala sekolah selain mengatur jalannya penyelenggaraan sekolah, juga harus dapat bekerjasama dan berkomunikasi dengan masyarakat; Berkewajiban membangkitkan semangat guru-guru dan pegawai sekolah untuk bekerja lebih baik; Membangun dan memelihara kekeluargaan, kekompakan dan persatuan antara guru-guru, pegawai dan murid-muridnya; Mengembangkan kurikulum; Mengetahui rencana sekolah dan tahu bagaimana menjalankannya, memperhatikan dan mengusahakan kesejahteraan karyawan. Supervisi ialah suatu aktivitas pembinaan yang direncanakan untuk membantu guru dan pegawai sekolah dalam melakukan pekerjaan secara efektif dan efisien. Supervisi kepala sekolah bukan hanya sekedar kontrol melihat apakah segala kegiatan telah dilaksanakan sesuai dengan rencana atau program yang telah digariskan, tetapi lebih dari itu. Supervisi kepala sekolah mencakup penentuan kondisi-kondisi atau syarat-syarat personel maupun material yang diperlukan untuk terciptanya situasi pembelajaran yang efektif.

Sesuai dengan amanat pasal 38 ayat (5), Badan Standar Nasional Pendidikan telah mengembangkan standar kepala sekolah yang kemudian diterbitkan Permendiknas Nomor 13 Tahun 2007 tentang Standar Kepala Sekolah/Madrasah. Dalam Pasal 1 ayat (1) Permendiknas tersebut ditetapkan bahwa untuk diangkat sebagai kepala sekolahtermasuk madrasah, seseorang wajib memenuhi standar kepala sekolah yang berlaku nasional. Lampiran Permendiknas tersebut pada intinya terdiri atas dua hal, yaitu kualifikasi dan kompetensi kepala sekolah. Kualifikasi kepala sekolah terdiri atas kualifikasi umum dan kualifikasi khusus, sedangkan kompetensi kepala sekolah terdiri atas lima dimensi, yaitu kepribadian, manajerial, kewirausahaan, supervisi dan sosial. (Sobahi, K. Dkk. 2010 : 210) Dalam rangka melaksanakan Undang-Undang Nomor 20 Tahun 2003 tentang Sistem Pendidikan Nasional, telah ditetapkan Peraturan Pemerintah Nomor 19 Tahun 2005 tentang 
Standar Nasional Pendidikan yang mencakup standar: (1) isi; (2) proses; (3) kompetensi lulusan; (4) pendidik dan tenaga kependidikan; (5) sarana dan prasarana; (6) pengelolaan; (7) pembiayaan; dan (8) standar penilaian pendidikan. Standar-standar tersebut di atas merupakan acuan dan sekaligus kriteria dalam peningkatan dan penjaminan mutu penyelenggaraan pendidikan. Salah satu standar yang memegang peran penting dalam peningkatan mutu pendidikan adalah standar pendidik dan tenaga kependidikan termasuk di dalamnya para pengawas satuan pendidikan.

Peran pengawasan pendidikan diatur secara khusus dalam PP 19 Tahun 2005 Pasal 55 dan 57 tentang Standar Pengelolaan yang meliputi pemantauan, supervisi, evaluasi, pelaporan, dan tindak lanjut hasil pengawasan. Pengaturan pengawasan pendidikan diatur pula dalam PP 74 Tahun 2008 tentang Guru pada Pasal 15 ayat 4 menjelaskan bahwa guru yang diangkat menjadi pengawas satuan pendidikan melaksanakan tugas pembimbingan dan pelatihan profesional guru dan tugas pengawasan. Peraturan Menteri Pendayagunaan Aparatur Negara dan Reformasi Birokrasi Nomor 21 Tahun 2010 tentang Jabatan Fungsional Pengawas Sekolah dan Angka Kreditnya selanjutnya menjadi acuan operasional yang menjadi landasan utama dalam melaksanakan tugas pokok pengawas sekolah. Tugas pokok pengawas sekolah adalah melaksanakan tugas pengawasan akademik dan manajerial pada satuan pendidikan yang meliputi penyusunan program pengawasan, pelaksanaan pembinaan terhadap guru dan kepala sekolah, pemantauan pelaksanaan delapan standar nasional pendidikan, penilaian kinerja guru dan kepala sekolah, pembimbingan dan pelatihan profesional guru, evaluasi hasil pelaksanaan program pengawasan, dan pelaksanaan tugas kepengawasan di daerah khusus. Dalam melaksanakan tugas pokoknya, pengawas sekolah berfungsi sebagai supervisor pendidikan atau pengawas pendidikan, baik pengawasan akademik maupun maupun pengawasan manajerial. Berkaitan dengan sasaran pengawasan akademik, pengawas sekolah bertugas membantu dan membina guru meningkatkan profesionalnya agar dapat mempertinggi kualitas proses dan hasil belajar siswa. Berkaitan dengan pengawasan manajerial, pengawas sekolah bertugas membantu kepala sekolah dan seluruh staf sekolah agar dapat meningkatkan mutu penyelenggaraan pendidikan pada sekolah yang dibinanya lebih efektif.

Pengawas satuan pendidikan adalah tenaga kependidikan profesional berstatus PNS yang diangkat dan diberi tugas, tanggung jawab dan wewenang secara penuh oleh pejabat berwenang untuk melaksanakan pengawasan akademik dan pengawasan manajerial melalui kegiatan pemantauan, penilaian, pembinaan, pelaporan dan tindak lanjut (Sujana, 2006) Hal ini dilakukan pengawas di sekolah yang merupakan binaannya. Peraturan Pemerintah No 19 Tahun 2005 tentang Standar Nasional Pendidikan ditandaskan pada Pasal 55 ayat 1, Pengawasan satuan Pendidikan memiliki peran dan tugas untuk Pemantauan, supervisi, evaluasi, pelaporan dan tindak lanjut hasil pengawasan yang harus dilakukan secara teratur dan kesinambungan. Lebih lanjut pada Pasal 57 ditegaskan, bahwa tugas supervisi meliputi : Supervisi akademik dan manajerial terhadap keterlaksanaan dan ketercapaian tujuan pendidikan disekolah. Peraturan Menteri Pendidikan Nasional Nomor 12 tahun 2007 tentang Standar Pengawas Sekolah/Madrasah berisi standar kualifikasi dan kompetensi pengawas sekolah. Standar kualifikasi menjelaskan persyaratan akademik dan nonakademik untuk diangkat menjadi pengawas sekolah. Standar kompetensi memuat seperangkat kemampuan yang harus dimiliki dan dikuasai pengawas sekolah untuk dapat melaksanakan tugas pokok, fungsi dan tanggung jawabnya.

Menurut Lumsdaine (1995), kreativitas adalah mempergunakan imajinasi dan berbagai kemungkinan yang diperoleh dari interaksi dengan ide atau gagasan, orang lain dan lingkungan untuk membuat koneksi dan hasil yang baru serta bermakna. Artinya mengembangkan pemikiran alternatif atau kemungkinan 
dengan berbagai cara sehingga mampu melihat sesuatu dari berbagai sudut pandang dalam interaksi individu dengan lingkungan sehingga diperoleh cara-cara baru untuk mencapai tujuan yang lebih bermakna. Berdasarkan pengertian di atas, dapat disimpulkan bahwa kreativitas adalah kemampuan guru untuk mempergunakan imajinasi dan berbagai kemungkinan yang diperoleh dari interaksi dengan ide atau gagasan, orang lain dan lingkungan untuk membuat koneksi dan hasil yang baru serta bermakna. Menurut Supriatna (2006), kreativitas adalah kemampuan cipta, karsa dan karya seseorang untuk dapat menciptakan sesuatu yang baru. Sesuatu yang baru itu dapat ditemukan dengan menghubungkan atau menggabungkan sesuatu yang sudah ada. Kreativitas adalah bakat yang dimiliki oleh setiap orang yang dapat dikembangkan dengan pelatihan dan aplikasi yang tepat. Banyak studi telah dilakukan tentang perilaku kreatif dari para musisi, ilmuwan besar, arsitek, pujangga, dan pelukis. Hasilnya adalah bahwa proses kreativitasnya sama, baik kreativitas itu terpusat pada pemecahan masalah sehari-hari, atau penemuan ilmiah tingkat tinggi. Guru diberi kemampuan untuk menyesuaikan diri dengan berbagai situasi dan tantangan perkembangan pendidikan. Perubahan dan perkembangan dalam dunia pendidikan berimplikasi kepada guru untuk dapat beradaptasi dengan cepat dan tepat. Seringkali tingkat keragaman dan kedalaman permasalahan dalam pendidikan, terutama menyangkut pembelajaran di sekolah sangat tinggi dan kompleks. Hal itu dikarenakan tantangan dan permasalahan pembelajaran dapat berasal dari faktor ekstern guru seperti siswa yang tidak semangat belajar, media pembelajaran yang kurang memadai, dsb. maupun internal guru. Guru seyogianya dapat memikirkan dan bertindak dengan cara yang tepat untuk dapat menguraikan kompleksitas tantangan dan memikirkan berbagai alternatif tindakan yang dapat dilakukan untuk menjawab berbagai masalah tersebut.

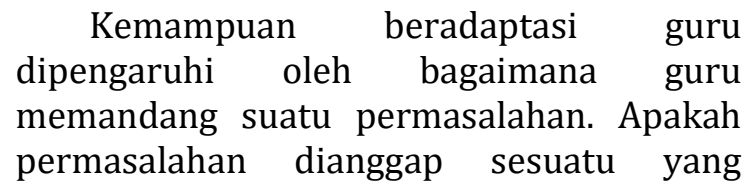

menyulitkan, merugikan, dan mengancam diri atau permasalahan dipandang sebagai tantangan yang membuat diri menjadi lebih tahu, terampil, atau mampu bertindak lebih baik. Orientasi memandang suatu persoalan merupakan kunci awal seorang guru memiliki kreativitas. Pandangan positif memfasilitasi berkembangnya imajinasi tentang kondisi yang harus dihadapi sehingga persoalan dapat dilihat secara komprehensif. Imajinasi berbagai pengalaman sendiri dan atau orang lain yang dimaknai sebagai proses belajar memberi peluang pada diri guru untuk melihat berbagai kemungkinan atau alternatif tindakan yang dapat dilakukan. Pengertian prestasi yang disampaikan oleh para ahli sangatlah bermacammacam dan bervariasi. Hal ini dikarenakan sudut pandang yang berbeda-beda dari para ahli itu sendiri. Perbedaan tersebut justru dapat saling melengkapi tentang pengertian prestasi. Menurut Arifin (2012:3) "Prestasi adalah hasil dari kemampuan, keterampilan dan sikap seseorang dalam menyelesaikan suatu hal. Sedangkan menurut Kamus Besar Bahasa Indonesia (2005: 895) "Prestasi adalah hasil yang telah dicapai (dari yang telah dilakukan, dikerjakan dan sebagainya). Prestasi merupakan hasil suatu usaha yang telah dilaksanakan menurut batas kemampuan dari pelaksanaan usaha tersebut. Prestasi merupakan hasil yang telah dicapai dari yang telah dilakukan, dikerjakan dan sebagainya (Sulchan,1987: 70). Prestasi adalah bukti keberhasilan usaha yang dapat dicapai (Winkel, 2002:45), prestasi tidak akan dicapai bila seseorang tidak melakukan kegiatan. Dari pendapat di atas dapat disimpulkan bahwa prestasi merupakan hasil usaha yang dicapai seseorang yang terlebih dalam melakukan kegiatan. Jika dilihat dari segi-segi yang menyangkut dengan sikap, minat, perhatian dan keterampilan murid. Prestasi yang dicapai dipengaruhi oleh beberapa hal antara lain motivasi dari luar maupun motivasi dari dalam yang keduanya saling berkaitan

Sekolah adalah sistem interaksi sosial suatu organisasi keseluruhan terdiri atas interaksi pribadi terkait bersama dalam suatu hubungan organik (Wayne dalam 
Atmodiwiro, 2000:37). Menurut Daryanto (1997:544), sekolah adalah bangunan atau lembaga untuk belajar serta tempat menerima dan memberi pelajaran. Menurut Mulyasa (2002:25) Sekolah merupakan suatu sistem dimana pelaksanaan yang berorientasikan pada kegiatan belajar mengajar dan pelaksanaan pengajaran yakni interaksi guru dengan murid, dalam rangka menyampaikan bahan pelajaran pada siswa dan untuk mencapai tujuan pengajaran Maka dari pendapat diatas disimpulkan bahwa sekolah ialah tempat dimana guru sebagai pengajar dalam membantu anak didiknya agar memperoleh pemahaman diri dan pengarahan dalam proses belajar me ngajar yang berguna kelak dalam masyarakat melalui pendidikan formal dan non formal. Jadi, sekolah sebagai suatu sistem sosial dibatasi oleh sekumpulan elemen kegiatan yang berinteraksi dan membentuk suatu kesatuan sosial sekolah yang demikian bersifat aktif kreatif artinya sekolah dapat menghasilkan sesuatu yang bermanfaat bagi masyarakat dalam hal ini adalah orang-orang yang terdidik. Dari definisi tersebut bahwa sekolah adalah suatu lembaga atau organisasi yang diberi wewenang untuk menyelenggarakan kegiatan pembelajaran. Sebagai suatu organisasi sekolah memiliki persyaratan tertentu. Jadi prestasi sekolah dapat diartikan sebagai penilaian hasil belajar dari proses kegiatan belajar mengajar yang dinyatakan dalam bentuk simbol, angka, huruf maupun kalimat yang dapat mencerminkan hasil yang sudah dicapai oleh setiap siswa dalam periode selama masih dalam bangku sekolah sehingga dapat membawa perubahan baik dari segi kognitif, afektif, dan psikomotorik yang dinyatakan dalam angka menurut kemampuan siswa dalam mengerjakan tes pelajaran (Sulchan, 1987:75). Dalam rangka penelitian mengenai Pengaruh Supervisi Kepala Sekolah dan Pengawas Sekolah Terhadap Kreativitas Guru serta Dampaknya terhadap Prestasi sekolah SMA Kabupaten Majalengka, kerangka pemikiran penulis dapat digambarkan berupa konstelasi antara variabel di mana variabel bebas berpengaruh positip terhadap variabel terikat dan dalam penelitian ini dapat dijabarkan sebagai berikut :
Variabel Supervisi Kepala Sekolah $\left(\mathrm{X}_{1}\right)$ berpengaruh positip terhadap variabel Kreativitas Guru (Y), variabel Supervisi Pengawas Sekolah $\left(\mathrm{X}_{2}\right)$ berpengaruh positip terhadap variabel Kreativitas Guru (Y), kemudian variabel $X_{1}$ dan $X_{2}$ berhubungan erat mempengaruhi terhadap variabel $\mathrm{Y}$, variabel Kreativitas Guru (Y) berdampak terhadap prestasi sekolah (Z). Kerangka pikir dari penelitian ini dapat digambarkan sebagai berikut :

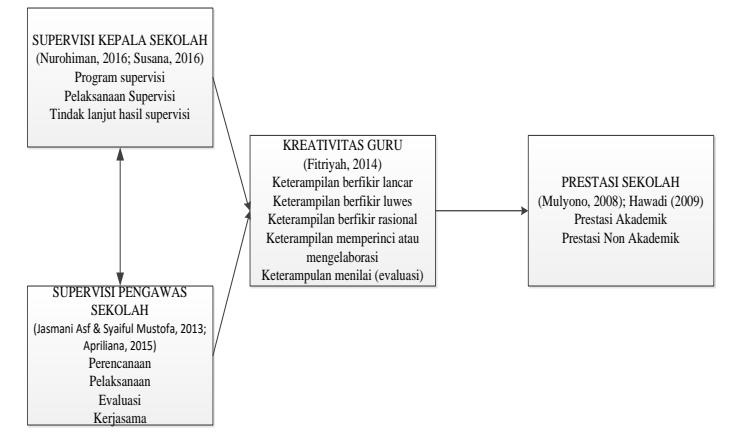

Gambar 1 Kerangka Pemikiran

Berdasarkan kerangka pemikiran di atas, dirumuskan hipotesis penelitian sebagai berikut :

1. Supervisi kepala sekolah SMA terhadap kreativitas guru di Kabupaten Majalengka, diasumsikan baik.

2. Supervisi pengawas sekolah SMA terhadap kreativitas guru di Kabupaten Majalengka, diasumsikan baik.

3. Supervisi kepala sekolah SMA dan pengawas sekolah SMA terhadap kreativitas guru di Kabupaten Majalengka, diasumsikan baik.

4. Kreativitas guru SMA terhadap prestasi sekolah di Kabupaten Majalengka, diasumsikan baik.

5. Supervisi kepala sekolah SMA terhadap kreativitas guru di Kabupaten Majalengka, diasumsikan baik.

6. Terdapat pengaruh signifikan supervisi pengawas sekolah SMA terhadap kreativitas guru di Kabupaten Majalengka.

7. Terdapat pengaruh signifikan supervisi kepala sekolah SMA dan pengawas sekolah SMA terhadap kreativitas guru di Kabupaten Majalengka.

8. Terdapat pengaruh signifikan kreativitas guru SMA terhadap prestasi sekolah di Kabupaten Majalengka. 


\section{METODE PENELITIAN}

Menurut Sugiyono (2014:6) "Metode penelitian dapat diartikan sebagai cara ilmiah untuk mendapatkan data yang valid dengan tujuan dapat ditemukan, dikembangkan, dan dibuktikan, suatu pengetahuan tertentu sehingga dapat digunakan untuk memahami, memecahkan, dan mengantisispasi masalah". Metode penelitian mencakup prosedur dan teknik penelitian. Metode penelitian merupakan langkah penting untuk memecahkan masalah-masalah penelitian. Dengan menguasai metode penelitian, bukan hanya dapat memecahkan berbagai masalah penelitian, namun juga dapat mengembangkan bidang keilmuan yang digeluti. Selain itu, memperbanyak penemuan-penemuan baru yang bermanfaat bagi masyarakat luas dan dunia pendidikan. Metode penelitian yang digunakan dalam penelitian ini adalah metode penelitian kuantitatif dengan analisis secara deskriptif dan verifikatif yaitu dengan cara mencari informasi tentang gejala yang ada, didefinisikan dengan jelas tujuan yang akan dicapai, merencanakan cara pendekatannya, mengumpulkan data sebagai bahan untuk membuat laporan serta melakukan pengujian hipotesis. Dalam penelitian ini penulis ingin mengetahui atau mengukur keterkaitan antara supervise dan pengawas sekolah terhadap kreativitas guru serta dampaknya pada prestasi sekolah. Variabel penelitian yang akan dikaji dalam penelitian ini dibagi menjadi dua variabel utama, yaitu variabel bebas $(\mathrm{X})$ yang terdiri dua variabel, yaitu supervise kepala sekolah $\left(\mathrm{X}_{1}\right)$ dan pengawas sekolah $\left(\mathrm{X}_{2}\right)$. Sedangkan variabel intervening $(Y)$ kreativitas guru serta variable terikat $(\mathrm{Z})$ yaitu prestasi sekolah.

Populasi dalam penelitian ini adalah guru SMA se-Kabupaten Majalengka yang berjumlah 886 orang. Penentuan jumlah sampel menggunakan rumus slovin yang dikembangkan Yamane dalam Jalaludin Rakhmat (2004:99). Dari hasil perhitungan rumus slovin didapat hasil sebesar 276 orang. Pengumpulan data primer dalam penelitian ini menggunakan teknik kuisioner yang merupakan suatu teknik pengumpulan data dengan cara membuat sejumlah pertanyaan yang diajukan kepada responden dengan maksud menjaring data langsung dari responden. Untuk mengukur setiap variabel penelitian menyusun instrumen mengacu pada indikator masing-masing variabel, kemudian dijabarkan pada butir-butir kuesioner yang dilengkapi dengan pilihan alternatif jawaban menggunakan skala likert. Sebuah alat ukur dapat dinyatakan baik apabila mempunyai reliabilitas yang baik pula, yaitu ketepatan alat ukur. Hal ini dimaksudkan bahwa ketepatan alat ukur ini akan sangat berpengaruh dalam menentukan layak tidaknya suatu alat ukur untuk digunakan dalam penelitian ini, maka penulis mengadakan uji coba angket di luar responden dan menganalisisnya dengan teknik analisis non-tes. Metode analisis verifikatif yang dilakukan dalam penelitian ini adalah dengan menggunakan analisis jalur (path analysis). Analisis utama yang dilakukan adalah untuk menguji konstruk jalur apakah teruji secara empiris atau tidak. Analisis selanjutnya dilakukan untuk mencari pengaruh langsung dan tidak langsung seperangkat variabel bebas terhadap variabel terikat. Selain itu analisis jalur merupakan suatu tipe analisis multivariate untuk mempelajari efek-efek langsung dan tidak langsung dari sejumlah variabel yang dihipotesiskan sebagai variabel sebab terhadap variabel lainnya yang disebut variabel akibat. Hubungan kausalitas antar variabel telah dibentuk dengan model berdasarkan landasan teori. Data dalam penelitian ini diolah dengan menggunakan program Statistical Package for Social Sciences (SPSS).

\section{HASIL PENELITIAN DAN PEMBAHASAN}

Jawaban terhadap rumusan masalah di atas, pada penelitian ini diselesaikan dengan analisis jalur (path analysis) yang merupakan pengembangan korelasi yang diurai menjadi beberapa interpretasi akibat yang ditimbulkannya. Lebih lanjut, analisis jalur mempunyai kedekatan dengan regresi berganda; atau dengan kata lain, regresi berganda merupakan bentuk khusus dari analisis jalur. Analisis jalur memiliki 
keunggulan bila dibandingkan dengan analisis regresi ataupun analisis korelasi. Kelebihan analisis jalur secara konsep dan teori adalah dapat mengetahui derajat hubungan antara variabel dependen, pengaruh langsung, pengaruh tidak langsung, total pengaruh dan pengaruh gabungan (simultan) serta pengujian hipotesis yang diukur secara parsial dan simultan. Pada penelitian ini akan diteliti mengenai kontribusi pengaruh supervisi kepala sekolah dan supervisi pengawas sekolah terhadap kreativitas guru yang memiliki dampak pada prestasi sekolah. Penyelesaian analisis jalur pada penelitian ini menggunakan bantuan software SPSS Versi 20.0 Secara diagram hasil analisis jalur digambarkan sebagai berikut:

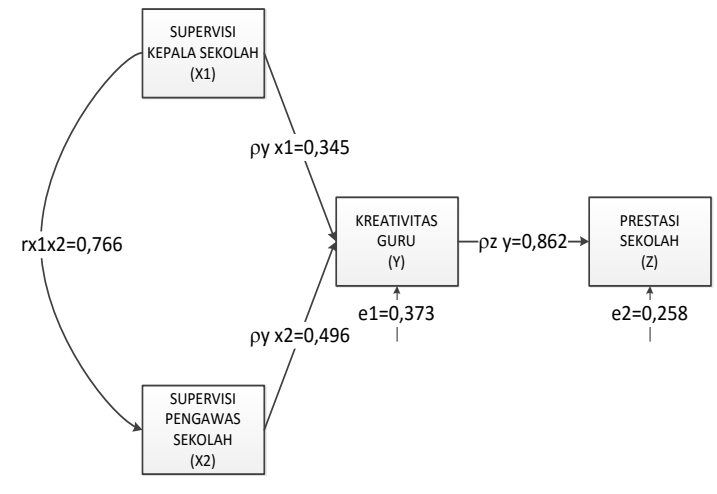

Gambar 2 Hasil Struktur Analisis Jalur

Dari data yang tertera pada gambar 2, diketahui bahwa hasil struktur analisis jalur di atas terdiri dari nilai koefisien korelasi dan koefisien jalur. Analisis terhadap koefisien korelasi diperoleh bahwa nilai koefisien korelasi antara supervisi kepala sekolah dan supervisi pengawas sekolah dengan nilai korelasi sebesar 0,766. Nilai tersebut mengindikasikan bahwa kedua variabel memiliki hubungan yang kuat. Selanjutnya, pada analisis jalur akan diteliti mengenai kontribusi pengaruh dari masingmasing konstruk dalam model analisis jalur. Gambar di atas, menunjukkan bahwa analisis jalur terbentuk oleh dua konstruk yaitu konstruk I adalah variabel supervisi kepala sekolah dan supervisi pengawas sekolah terhadap kreativitas guru dan konstruk II adalah variabel kinerja guru terhadap prestasi sekolah. Hasil analisis terhadap koefisien jalur untuk konstruk I didapat bahwa variabel supervisi pengawas sekolah memiliki nilai koefisien jalur tertinggi bila dibandingkan dengan variabel supervisi kepala sekolah. Koefisien jalur untuk variabel supervisi pengawas sekolah terhadap prestasi sekolah sebesar 0,496. Nilai koefisien jalur untuk konstruk II antara variabel kreativitas guru dengan prestasi sekolah memiliki nilai koefisien jalur sebesar 0,862. Dilihat dari hasil analisis koefisien jalur ternyata variabel kreativitas guru memiliki hasil nilai koefisien jalur sangat signifikan terhadap prestasi sekolah SMA se-Kabupaten Majalengka. Analisis kontribusi pengaruh untuk konstruk I yaitu pengaruh yang diberikan oleh variabel supervisi kepala sekolah dan supervisi pengawas sekolah terhadap kreativitas guru yang diukur secara parsial dan simultan dapat diuraikan sebagai berikut :

\section{a. Pengaruh Langsung}

Pengaruh langsung dari variabel supervisi kepala sekolah terhadap kreativitas guru dengan nilai koefisien jalur sebesar 0,345; maka nilai pengaruh langsungnya sebesar $(0,345)^{2} \times 100 \%=$ $11,90 \%$.

Pengaruh langsung dari variabel supervisi pengawas sekolah terhadap kreativitas guru dengan nilai koefisien jalur sebesar $(0,496)^{2} \times 100 \%=24,60 \%$.

b. Pengaruh Tidak Langsung

Pengaruh tidak langsung dari variabel supervisi kepala sekolah terhadap kreativitas guru melalui supervisi pengawas sekolah sebesar $(0,345 \times 0,766$ $\mathrm{x} 0,496) \times 100 \%=13,11 \%$.

Pengaruh tidak langsung dari variabel supervisi pengawas sekolah terhadap kreativitas guru melalui supervisi kepala sekolah sebesar $(0,496 \times 0,766 \times 0,345) \times$ $100 \%=13,11 \%$.

\section{c. Total Pengaruh}

Total pengaruh dari variabel supervisi kepala sekolah terhadap kreativitas guru baik secara langsung maupun tidak langsung sebesar $(11,90 \%+13,11 \%)=$ $25,01 \%$.

Total pengaruh variabel supervisi pengawas sekolah terhadap kreativitas guru baik secara langsung maupun tidak 
langsung sebesar $(24,60 \%+13,11 \%)=$ $37,71 \%$.

\section{d. Koefisien Determinasi}

Total pengaruh secara simultan yang diberikan oleh variabel supervisi kepala sekolah dan supervisi pengawas sekolah terhadap kreativitas guru sebesar $25,01 \%+37,71 \%=62,72 \%$.

Supervisi bersangkut paut dengan semua upaya penelitian yang tertuju pada semua aspek yang merupakan faktor penentu keberhasilan pendidikan. Dengan mengetahui kondisi aspek-aspek yang berkaitan dengan pendidikan secara rinci dan akurat, dapat diketahui dengan tepat apa yang diperlukan untuk meningkatkan kualitas pendidikan. Kegiatan supervisi idealnya melihat hal-hal negatif untuk diupayakan menjadi positif dan melihat mana yang positif untuk dapat ditingkatkan menjadi lebih baik lagi. Lebih dari itu, dalam pelaksanaannya bukan mencarimencari kesalahan tetapi lebih terfokus pada unsur pembinaan, agar kondisi pekerjaan yang sedang disupervisi dapat diketahui kekurangannya untuk dapat diberitahu bagian yang perlu diperbaiki. Dengan kata lain, supervisi yang dilakukan baik oleh kepala sekolah maupun pengawas pendidikan, dimaksudkan untuk meningkatkan kualitas proses pembelajaran sehingga bermakna bagi peserta didik. Supervisi merupakan kegiatan yang berhubungan dengan berbagai usaha perbaikan untuk meningkatkan kualitas guru. Dengan meningkatnya kualitas guru, diharapkan dapat berjalan selaras dengan kualitas pembelajaran di kelas. Kualitas pembelajaran yang dimaksud mencakup proses dan hasil yang dicapai setelah proses pembelajaran berlangsung. Dan pada akhirnya bermuara pada meningkatnya kualitas pendidikan. Hasil pengujian hipotesis membuktikan bahwa supervisi yang dilaksanakan oleh kepala sekolah dan pengawas sekolah berpengaruh positif dan signifikan terhadap kreativitas guru. Hal ini menunjukkan bahwa semakin tinggi tingkat kreativitasnya, maka semakin tinggi pula kualitasnya. Penelitian ini membuktikan bahwa guru merupakan salah satu kunci dalam meningkatkan kualitas proses dari pembelajaran yang dihasilkan dari guruguru yang memiliki kreativitas yang tinggi.

Kualitas proses pembelajaran tergantung pada kemampuan guru dalam kegiatan pembelajaran, sedangkan kualitas hasil pembelajaran biasanya ditunjukkan oleh prestasi. Jika proses pembelajaran tidak berkualitas, maka dapat dipastikan $90 \%$ prestasi juga tidak akan baik. Sebaliknya, jika proses pembelajaran berkualitas besar kemungkinan prestasi pun akan baik. Makmun, (2003: 5) menyatakan bahwa guru ialah orang dewasa (yang karena jabatannya secara formal) selalu mengusahakan terciptanya situasi yang tepat (mengajar) sehingga memungkinkan terjadinya proses pengalaman belajar (learning experiences) pada diri siswa, dengan mengerahkan segala sumber (learning resources) dan menggunakan strategi belajar mengajar (teaching learning strategy) yang tepat (appropriate). Belajar bukanlah proses untuk menjadikan siswa sebagai "ahli" pada mata pelajaran tertentu. Siswa lebih membutuhkan "pengalaman" dalam belajar, bukan "pengetahuan". Karena itu, kompetensi guru menjadi syarat utama tercapainya kualitas belajar yang baik. Guru yang kompeten akan "meniadakan" problematika belajar akibat kurikulum. Kompetensi guru harus berpijak pada kemampuan guru dalam mengajarkan materi pelajaran secara menarik, inovatif, dan kreatif yang mampu membangkitkan kegairahan siswa dalam belajar. Pembelajaran dibangun oleh manusia sedikit demi sedikit, yang hasilnya diperluas melalui konteks yang terbatas (sempit) dan tidak sekonyong-konyong. Pembelajaran bukanlah seperangkat fakta, konsep atau kaidah yang siap untuk diambil dan diingat. Implementasi pendekatan konstruktivisme dalam pembelajarandiwujudkan dalam bentuk pembelajaran yang berpusat pada siswa (student center). Guru dituntut untuk menciptakan suasana belajar sedemikian rupa, sehingga siswa bekerja sama secara gotong royong (cooperative learning) Guru tidak boleh nyaman dengan cara belajar yang satu arah. Guru tidak lagi dapat bertahan pada otoritas belajar yang berlebihan. Bahkan guru harus mampu membuka ruang siswa menjadi aktif belajar 
dan banyak bertanya di kelas. Apalagi saat ini, ada kesan guru makin tidak berkembang, hanya datang, mengajar, pulang dan lebih sibuk dengan urusan profesi keguruannya. Di sisi lain, sikap guru dalam mengajar juga patut mendapat perhatian. Banyak sikap guru yang tidak bangga terhadap mata pelajaran yang diampunya. Banyak guru yang mengajar tidak dengan hati, melainkan dianggap sebagai profesi. Akibatnya siswa makin acuh karena sikap guru yang tidak antusias dalam mengajar dan penguasaan materi ajar yang minim.

Beberapa sikap guru yang penting dalam konteks belajar di masa sekarang adalah: a) orientasi belajar yang lebih praktis, b) bertumpu pada siswa dalam memperoleh pengalaman, c)kreasi guru dalam mengajar harus lebih luas, d) penyederhanaan materi pelajaran, dan e) metode belajar yang menarik dan menyenangkan. Terlepas dari semua kondisi ideal di atas, salah satu cara lainnya untuk meningkatkan kompetensi guru adalah dengan meningkatkan kualitas supervisi akademik yang dilakukan pengawas. Dan kualitas supervisi akademik juga tergantung pada kualitas kepala sekolah dan juga kualitas pengawas sebagai pengawas pada pelaksanaan supervisi. Penjelasan tersebut sejalan dengan hasil uji hipotesis bahwa guru yang memiliki kreativitas dalam proses pembelajaran sangat berpengaruh positif dan signifikan terhadap prestasi yang dihasilkan oleh sekolah. Prestasi dalam sekolah terdiri dari prestasi akademik dan prestasi non akademik. Prestasi akademik berkaitan dengan proses kegiatan pembelajaran, sedangkan prestasi non akademik berakaitan dengan proses penunjang pembelajaran lainnya.

\section{SIMPULAN}

Hasil penelitian menyatakan bahwa persepsi guru tentang supervisi kepala sekolah dikategorikan baik. Hasil ini akan memberikan petunjuk bagi para kepala sekolah SMA untuk dapat meningkatkan dan mempertahankan kegiatan supervisi. Di dalam tatanan supervisi pembelajaran, perencanaan, pelakasanaan dan tindak lanjut dari supervisi merupakan kegiatan yang sangat penting untuk dilakukan sekolah guna merencanakan, melaksanakan serta untuk menindaklanjuti seluruh kegiatan supervisi yang nantinya akan dilakukan oleh kepala sekolah. Reward dan punishment perlu juga diterapkan agar kreativitas guru semakin meningkat. Hasil penelitian menyatakan bahwa persepsi guru tentang supervisi pengawas sekolah dikategorikan baik. Hasil penelitian memberikan petunjuk bagi pengawas sekolah untuk dapat meningkatkan dan mempertahankan kegiatan supervisi yang berkaitan dengan aspek perencanaan, pelaksanaan, evaluasi dan meningkatkan pola kerjasama dengan sekolah sehingga hubungan personal antara pengawas dengan sekolah dapat terjalin dengan baik.

Hasil penelitian menyatakan bahwa kreativitas guru dikategorikan tinggi. Hasil ini akan memberikan petunjuk bagi SMA di Kabupaten Majalengka untuk terus dapat meningkatkan kreativitas guru, melalui memberikan kebebasan dalam berkreasi, memberikan insentif bagi guru yang memiliki prestasi sehingga hal ini menjadi harapan yang lebih baik bagi guru untuk meningkatkan kreativitasnya dalam kegiatan pembelajaran. Hasil penelitian menyatakan bahwa prestasi sekolah dikategorikan baik. Hasil ini memberikan petunjuk bagi kepala SMA di Kabupaten Majalengka untuk dapat mempertahankan dan terus meningkatkan prestasinya baik di bidang akademik maupun non akademik. Hasil penelitian menyatakan bahwa terdapat pengaruh supervisi kepala sekolah terhadap kreativitas guru. Kontribusi pengaruh supervisi kepala sekolah terhadap kreativitas guru adalah sebesar 25,01\%.

Hasil penelitian menyatakan bahwa terdapat pengaruh supervisi pengawas sekolah terhadap kreativitas guru dengan kontribusi sebesar 37,71\%. Hal ini menunjukkann bahwa persepsi guru tentang supervisi pengawas sekolah berpengaruh terhadap kreativitas guru. Hasil penelitian menyatakan bahwa terdapat pengaruh antara persepsi guru tentang supervisi kepala sekolah dan supervisi pengawas sekolah terhadap kreativitas guru. Kontribusi kedua variabel 
persepsi guru tentang supervisi kepala sekolah dan supervisi pengawas sekolah terhadap kreativitas guru yaitu sebesar $62,72 \%$. Hal ini menunjukkan bahwa persepsi guru tentang supervisi kepala sekolah dan supervisi pengawas sekolah cukup berpengaruh terhadap kreativitas guru dalam suatu proses kegiatan belajar mengajar. Hasil penelitian menyatakan bahwa terdapat pengaruh kreativitas guru terhadap prestasi sekolah dengan besaran kontribusi 74,30\%. Hal ini menunjukkan bahwa kreativitas guru berpengaruh terhadap prestasi sekolah.

\section{DAFTAR PUSTAKA}

Aqib, Zainal. (2002). Profesionalisme dalam Pembelajaran. Surabaya; Insan Cendikia.

Ani M Hasan. (2003). Pengembangan Profesionalisme Guru di Abad Pengetahuan. Jakarta; Rineka Cipta.

Azwar, S. Schuler, R dan Suzan E. Jackson. (1999). Manajemen Sumber Daya Manusia. Yogyakarta; Pustaka Pelajar.

Akadum. (1999). Potret Guru Memasuki Milenium. Jakarta; Cipta Rineka.

Arikunto, Suharsimi. (2005). Prosedur Penelitian Suatu Pendekatan. Jakarta; Cipta Rineka.

Arikunto, S. (2006). Prosedur Penelitian. Yogyakarta; Pustaka Pelajar Offset.

Agus Tulus, Moh. (1996). Manajemen Sumber Daya Manusia. Jakarta; Gramedia Pustaka.

A.S, Moenir. (1987). Pendekatan Manusiawi dan Organisasi. Jakarta; Gramedia Pustaka Utama

Arikunto, Suharsimi. (1998). Prosedur Penelitian. Jakarta : PT. Rineka Cipta.

Ahmad Tohardi. (2002). Pemahaman Praktis Manajemen SDM. Bandung: CV. Munandar.

Ani M. Hasan. (2003). Pengembangan Profesionalisme Guru di Abad Modern. Yogyakarta; Pustaka Pelajar.
Bernardin, HJ. dan Russel J.E.A. (1993). Reformasi Pendidikan Human Resource Management. Yogyakarta : Lappera Pustaka. Utama

Cooper, Donald $R$, Pamela S. Schindler. (2003). Business Research Methods. New York: McGraw-Hill/Irwin.

Donnelly, Konopaske. (2008). Organizations Behavior Structure. Processes. Thirteenth Edition. McGraw Hill Inc. Gitosudarmo.

Dessler, Gary. (2004). Manajemen Sumber Daya Manusia; Jilid 1 Edisi Kesembilan. Jakarta; PT Indeks.

Djamarah dan Aswan Zain. (2002). Strategi Belajar Mengajar. Jakarta; Cipta Rineka.

Fathoni, Abdurrahmat. (2006). Manajemen Sumber Daya Manusia. Bandung; Rineka. Cipta.

Hariandja, Marihot T.E. (2002). Manajemen Sumber Daya Manusia. Jakarta: Grasindo.

Hasibuan, Malayu, S.P. (2003). Manajemen Dasar, Pengertian dan Masalah. Jakarta; PT Gunung Agung.

Hamalik, Oemar. (1985). Psikologi Belajar. Jakarta; Cipta Rineka.

(2007). Pengembangan SDM. Jakarta : PT. Rineka Cipta.

Lieke Lianadevi. (tt) Fungsi Sosial Hak atas Tanah dalam Pengadaan Tanah. Yogyakarta, Pustaka Pelajar

Mangkunegara, A. A, Ashly \& Tony Edwards. (2000). Introduction to Human Resource. Bandung; Pustaka Setia. , (2005). Manajemen Sumber daya Manusia. Bandung; PT Remaja Rosdakarya.

Mangkuprawira, Syafri. (2003). Manajemen Sumber Daya Manusia Strategik. Jakarta; Gramedia Pustaka Utama.

(2009). Manajemen dan Sumber Daya Manusia. Jakarta; PT. Gramedia. 
Nitisemito, A.S. (1982). Reliabilitas dan Validitas. Yogyakarta : Pustaka Pelajar.

Robert L. Mathis \& John H. Jackson. (2006). Human Resources Management; Edisi sepuluh, Yogyakarta; Penerbit Salemba Empat.

Rivai, Veithzal. \& Sagala, S. (2009). Manajemen Sumber Daya Manusia untuk Perusahaan. Jakarta: Rajagrafindo Persada.

Ranupandojo, Hidjrachman dan Suad Husnan. (2002). Manajemen Personalia, Edisi 4. Yogyakarta; Pustaka Binawan Presindo.

Syah,Muhibbin. (1999). Psikologi Belajar. Jakarta: Logos Wacana Ilmu.

Steers, R. M., and Porter, L. W. (1991). Motivation and Pwork Behavior. Yogyakarta; Pustaka Pelajar Offset.
S, Ambar Teguh dan Rosidah. (2005). Manajemen Sumber Daya Manusia. Bandung; Penerbit PT Aghini.

Singodimedjo, Markum. (2000). Evaluasi Kinerja SDM. Bandung; PT. Penerbit Kencana.

Sugiyono. (2008). Metode Penelitian Kunatitatif Kualitatif dan R\&D. Bandung; Alfabeta.

Usman. (2006). Pendekatan Populer dan Praktis. Bandung. Bandung; CV Pustaka Setia.

Veithzal, Rivai. (2005). Research Methods in Finance and Banking. Jakarta; Gramedia Pustaka Utama.

Widjaja, A.W. (1986). Peranan Motivasi Dalam Kepemimpinan. Bandung; CV. Akademika Pressindo.

\section{BIOGRAFI PENULIS}

\begin{tabular}{|l|l|}
\hline & $\begin{array}{l}\text { Mohamad Ali, Mahasiswa Program Pascasajrana Magister Ilmu Administrasi, } \\
\text { Universitas Majalengka, Provinsi Jawa Barat, Indonesia } \\
\text { Email: mohamadali@gmail.com }\end{array}$ \\
\hline
\end{tabular}

